\title{
Early Prediction of Premature Atherosclerosis in Children with End Stage Renal Disease(ESRD) on Regular Haemodialysis, A Single Centre Experience
}

\author{
Dr. Mohamed A.El-Gamasy \\ Assistant Professer of Pediatrics, Tanta Faculty of Medicine, Tanta University, Egypt. \\ Vice Director of Pediatric Nephrology, Tanta Nephrology and Dialysis Unit, Tanta University Hospital \\ mgamsy@gmail.com
}

\begin{abstract}
Introduction: Chronic renal failure is associated with atherosclerosis and increased incidence of cardiovascular morbidity and mortality.

The aim of this work was to compare between children with ESRD under regular HD and healthy controls as regard serum levels of lipids as early predictors of premature atherosclerosis proven by common carotid intima-media thickness (CCA -IMT).

Methods: The present study was carried out on 45 children with ESRD on regular hemodialysis in an University hospital and 30 healthy age and sex matched children were serving as controls.All subjects were subjected to thorough history taking, clinical examination including anthropometric measurement and blood pressure measurements, routine laboratory assessments measuring complete blood picture, C-reactive protein, blood urea and serum Creatinine, lipid profile including serum levels of total cholesterol, triglycerides(TG), low density lipoprotein (LDL) and high density lipoprotein (HDL)and radiological assessment using B-mode Doppler ultrasonography to measure common carotid artery intima media thickness (CCA-IMT) to detect presence and extent of atherosclerosis.
\end{abstract}

Results: There was significant increase in serum levels of triglyceride, cholesterol and LDL and a significant decrease in HDL in dialysis children when compared to healthy controls. There was also a highly significant increase in CCA-IMT of the patients group when compared to the controls $(\mathrm{P}<0.001)$ with significant positive correlation with duration of dialysis and serum TG and a significant negative correlation with serum HDL.

Conclusions: Increased serum levels of TG, cholesterol, LDL and decreased serum level of HDL are early predictors for premature atherosclerosis in children with ESRD.

Keywords: Atherosclerosis, Children, Haemodialysis, Chronic Renal.

\section{INTRODUCTION}

Background: Cardiovascular disease accounts for one quarter of deaths in children and adults younger than 30 years old who started treatment of end stage renal disease(ESRD) at their childhood period $(1,2)$. Dyslipidemia became frequent in long term survivors undergoing maintenance hemodialysis due to improvement of dialysis adequacy $(3,4,5)$.

The aim of this work was to compare between children with ESRD under regular HD and healthy controls as regard serum levels of lipids as early predictors of premature atherosclerosis proven by common carotid intima-media thickness (CCA -IMT). 
Early Prediction of Premature Atherosclerosis in Children with End Stage Renal Disease(ESRD) on Regular Haemodialysis, A Single Centre Experience

\section{SubJects AND MethodS}

Sample Size, Design of the Study and Setting: The present study was carried out after approval from research ethical committee centre of Tanta University Hospital (TUH) and obtaining informed written consents from parents of included children, in Paediatric Nephrology Unit of Paediatric Department, Tanta University Hospital from August 2016 to August 2017 on 45 children with ESRD on regular haemodialysis (HD). Their ages ranged from 4 to 19 years with their mean $13.87 \pm 3.83$. They were 27 males and 18 females. All patients were undergoing regular HD, three times per week, with each dialysis session lasting for three to four hours Thirty healthy children matched in age and sex distribution were serving as control group. Their ages ranged from 4 to 19 years with their mean $13.8 \pm 3.8$. They were 15 males and 15 females. Patients were dialyzed on Fresenius 4008- B dialysis machine (Germany) at blood flow rate $=2.5 \mathrm{x}$ weight $(\mathrm{kg})+100 \mathrm{ml} / \mathrm{min}$., using polysulphane hollow fiber dialyzers suitable for the surface area of the patients (Fresenius F3 $=0.4 \mathrm{~m}^{2}, \mathrm{~F} 4=0.7 \mathrm{~m}^{2}, \mathrm{~F} 5=1.0$ $\mathrm{m}^{2}$ and $\mathrm{F} 6=1.2 \mathrm{~m}^{2}$ ). Bicarbonate dialysis solutions were used. All patients were receiving supportive therapy in the form of subcutaneous erythropoietin in a dose of $50 \mathrm{IU} / \mathrm{Kg} / \mathrm{session}$, IV iron dextran $100 \mathrm{mg} / \mathrm{Kg} / \mathrm{week}$, oral folic acid $1 \mathrm{mg} /$ day, oral calcium $1000 \mathrm{mg} /$ day, oral vitamin D (one alpha) in a dose of 0.01-0.05 $\mu \mathrm{g} / \mathrm{Kg} / \mathrm{day}$ and oral antihypertensive medications for hypertensive patients.

Inclusion Criteria: All children with ESRD and treated by regular maintenance haemodialysis.

Exclusion Criteria: Familial hypertriglyceridemia, Diabetes Mellitus, Congeital Heart Disease and obesity.

All patients and controls were subjected to the following History taking including duration of dialysis, Clinical examination including anthropometric measurements in the dialysis free day and blood pressure measurements,

Anthropometric measurements (weight, height and midarm circumference (MAC) by CDC growth charts developed by the National Center for Health Statistics in collaboration with the National Center for Chronic Disease Pretension and Health.

Promotion (6) They were expressed as percent of ideal for age. Ideal measurement is defined as the 50th percentile for age.

Arterial blood pressure was measured by the auscultatory method using a mercury sphygmomanometer with the patient in the semi setting position after 10 minutes of rest, in the non-fistula arm using an appropriate sized cuff. Arterial blood pressure was taken as the mean value of 3 successive readings in 3 different days. The mean arterial blood pressure was measured using the following equation:

Mean arterial BP=Diastolic BP $+1 / 3$ Pulse pressure

While, the pulse pressure equals systolic BP - diastolic BP (7)

The laboratory investigations done just predialysis and sent directly to the laboratory including haemoglobin level and serum creatinine, serum albumin, $C$ reactive protein (CRP), Serum cholesterol, triglyceride, high density lipoprotein (HDL) and low density lipoprotein (LDL) $(6,7,8)$.

The radiological assessments included measurement of Common Carotid Artery Intima-Media thickness (CCA-IMT). VALIDITY OF CCA-IMT MEASUREMENT

CCA-IMT measured by well trained diagnostic radiologist in department of Diagnostic Radiology of TUH by Doppler high resolution B-mode ultrasonography (US), using (Siemens Sono-Line G60F, Germany with 
Early Prediction of Premature Atherosclerosis in Children with End Stage Renal Disease(ESRD) on Regular Haemodialysis, A Single Centre Experience

transducer frequency 5-10 MHz linear probe for carotid arteries). CCA-IMT indicated the structural changes in arterial tree. CCA- IMT was measured on the far wall at $4 \mathrm{~cm}$ segment preceding the carotid bifurcation. The median Measurements of a CCA- IMT were always performed in plaque-free arterial segments in CCA.

Arteries were scanned longitudinally and transversely to determine the presence of plaques. A localized echostructure encroaching into the vessel lumen was considered to be plaque when the arterial wall was $>50 \%$ thicker than the neighbouring sites. Highly echogenic plaques producing bright white echoes with shadowing were considered to be calcifications [9 \& 10]. Arterial calcifications in each arterial region were quantified qualitatively as absent ( 0 ) or present (1). The final overall score was obtained by the addition of calcifications from all studied zones. The final score ranged from 0 (absence of calcium deposits), to 3 (calcifications present in all arterial segments examined) (11). Assessment of arterial stiffeness index by measurement of CCA diameter and CCA intima-media thickness(IMT): measured by high resolution B-mode ultrasonography (Siemens Sono-Line G60F, Germany, using 5-10 MHz transducer) enabling assessment of arterial wall displacement during the cardiac cycle which was measured on the far wall at the same level as the diameter measurements and were always performed in plaque-free arterial segments in CCA (11)

\section{Statistical Analysis}

Statistical analysis was performed with Statistical Package for Social Science (SPSS version 17). For quantitative data, the mean and the standard deviation were calculated, Chi-square was done for qualitative data, comparison between the

Studied groups was performed with student $\mathrm{t}$-test, with $\mathrm{P}<0.05$ were considered statistically significant. Correlation between variables was evaluated using Pearson's correlation coefficient (12).

\section{The Results}

Table (1) summarize demographic data of the studied patients and controls. The decline in anthropometric measures of studied patients that there was significant growth retardation in children with ESRD as compared to controls (mean value of weight $30.1 \pm 10.1 \mathrm{~kg}$ versus $52.03 \pm 14.3 \mathrm{~kg})(\mathrm{p}<0.001)$ and mean value of height $131 \pm 15.01 \mathrm{~cm}$ versus $153.1 \pm 16.14 \mathrm{~cm})(\mathrm{p}<0.001)$ and mean value of MAC $17.46 \pm 3.71 \mathrm{CM}$ versus $22.73 \pm 3.55$ $\mathrm{cm})(\mathrm{p}<0.001)$. There was a significant increase in both systolic and diastolic blood pressure values in patients group compared to the controls (mean value of systolic blood pressure $139 \pm 10.04 \mathrm{mmHg}$ versus $114 \pm 7.59$ $\mathrm{mmHg})(\mathrm{p}<0.001)$ and mean value of diastolic blood pressure $95.5 \pm 7.42 \mathrm{mmHg}$ versus $74 \pm 5.98 \mathrm{mmHg})$ $(\mathrm{p}<0.001)$ Table $(2)$ summarize routine laboratory data of the studied patients and controls. There was a highly significant decrease in serum albumin and haemoglobin level in patients as compared to the controls (mean value of albumin $3.94 \pm 0.27 \mathrm{gm} / \mathrm{dl}$ versus $5.11 \pm 0.59 \mathrm{gm} / \mathrm{l})(\mathrm{p}<0.001)$ and mean value of $\mathrm{HB} 8.11 \pm 1.99 \mathrm{~g} / \mathrm{dl}$ versus $12.2 \pm 0.65 \mathrm{~g} / \mathrm{dl})(\mathrm{p}<0.001)(\mathrm{P}=0.001)$. There was highly significant increase in CRP in patients as compared to the controls (mean value $37.5 \pm 7.52 \mathrm{mg} / \mathrm{l}$ versus $0.7 \pm 0.08 \mathrm{mg} / \mathrm{l})(\mathrm{p}<0.001)(\mathrm{P}=0.001)$. Table (3) summarize lipid panel and CCA-IMT data of the studied patients and controls. There was a highly significant increase in the serum TG and highly significant decrease in the serum HDL of the patients group when compared to the controls (mean value of serum TG $156.93 \pm 14.49 \mathrm{mg} / \mathrm{dl}$ versus $77.44 \pm 13.15 \mathrm{mg} / \mathrm{dl})(\mathrm{p}<0.001)$ while mean value of HDL $29.32 \pm 3.78 \mathrm{mg} / \mathrm{dl}$ versus $45.25 \pm 2.79 \mathrm{mg} / \mathrm{dl})(\mathrm{p}<0.001)(\mathrm{P}<0.001)$.

There was also statistically significant increase in serum levels of cholesterol and LDL in dialysis children (mean values were $222.06 \pm 32.26$ and $150.06 \pm 22.63 \mathrm{mg} / \mathrm{dl}$ respectively) when compared to healthy controls (mean values were $159.62 \pm 29.83$ and $90.39 \pm 8.8$ respectively $(\mathrm{p}<0.001)$. 
Early Prediction of Premature Atherosclerosis in Children with End Stage Renal Disease(ESRD) on Regular Haemodialysis, A Single Centre Experience

Regarding CCA-IMT results in our study, There was a highly significant increase in CCA-IMT of the patients group when compared to the controls (mean value $579.6 \pm 162.01$ um versus $336 \pm 52.8 \mathrm{um})(\mathrm{P}<0.001)$. Table (4) and figures. (1-4) shows correlations between different studied parameters in patient group, Regarding CCA-IMT correlations with different studied parameters, there is significant positive correlation between the mean CCA-IMT and the dialysis duration $(\mathrm{r}=0.291)(\mathrm{p}=0.047)$. There is also significant positive correlation between CCA IMT and serum level of triglycerides $(r=-0.455)(p=0.019)$. In contrary, there is a significant negative correlation between CCA IMT and serum level of albumin $(r=-0.229)(p=0.049)$ and serum level of HDL $(\mathrm{r}=-0.411)(\mathrm{p}=0.019)$. In our studied patients, There is a significant negative correlation between serum level of HDL and duration of dialysis. $(\mathrm{r}=-0.339)(\mathrm{P}=0.021)$. While there is a significant positive correlation between and HDL and serum level of albumin $(\mathrm{r}=0.399)(\mathrm{P}=0.028)$. And there is a significant positive correlation between serum level of triglycerides and duration of dialysis $(\mathrm{r}=0.021)(\mathrm{P}=0.038)$. While a significant negative correlation between serum level of triglycerides and serum levels of albumin $(r=-0.400)(P=0.031)$.

Table1. Demographic Data of Studied Patients and Controls

\begin{tabular}{|c|c|c|c|c|c|}
\hline & \multicolumn{2}{|c|}{ Groups } & \multicolumn{2}{|c|}{ Statistical test } \\
\hline & & Patients $(\mathrm{No}=45)$ & Control $(\mathrm{No}=30)$ & $\operatorname{tor} \mathrm{X}^{2}$ & P-value \\
\hline \multirow[t]{2}{*}{ Age (Years) } & Range & $4-19$ & $4-19$ & \multirow[t]{2}{*}{$t=0.01$} & \multirow[t]{2}{*}{1.00} \\
\hline & Mean \pm SD & $13.87 \pm 3.83$ & $13.8 \pm 3.8$ & & \\
\hline \multirow[t]{2}{*}{ Sex } & Male No(\%) & $27(60 \%)$ & $15(50 \%)$ & \multirow[t]{2}{*}{$X^{2}=0.32$} & \multirow[t]{2}{*}{$>0.05$} \\
\hline & Female No(\%) & $18(40 \%)$ & $15(50 \%)$ & & \\
\hline \multirow[t]{2}{*}{ Weight (kg) } & Range & $14-53$ & $18-71$ & \multirow[t]{2}{*}{$t=6.325$} & \multirow[t]{2}{*}{$<0.001$} \\
\hline & Mean \pm SD & $30.10 \pm 10.1$ & $52.03 \pm 14.3$ & & \\
\hline \multirow[t]{2}{*}{ Height (cm) } & Range & $95-157$ & $103-170$ & \multirow[t]{2}{*}{$t=9.201$} & \multirow[t]{2}{*}{$<0.001^{* *}$} \\
\hline & Mean \pm SD & $131 \pm 15.01$ & $153.1 \pm 16.14$ & & \\
\hline \multirow[t]{2}{*}{ MAC (cm) } & Range & $12-24$ & $15-27$ & \multirow[t]{2}{*}{$\mathrm{t}=4.523$} & \multirow[t]{2}{*}{$0.021^{* *}$} \\
\hline & Mean \pm SD & $17.46 \pm 3.71$ & $22.73 \pm 3.55$ & & \\
\hline \multirow{2}{*}{$\begin{array}{c}\text { Duration of } \\
\text { Dialyses (months) }\end{array}$} & Range & $12-120$ & & & \\
\hline & Mean \pm SD & $67.46 \pm 37.30$ & & & \\
\hline \multirow{2}{*}{$\begin{array}{l}\text { Pulse pressure } \\
\text { (mmHg) }\end{array}$} & Range & $25-70$ & $25-50$ & \multirow[t]{2}{*}{$\mathrm{t}=6.325$} & \multirow[t]{2}{*}{0.004} \\
\hline & Mean \pm SD & $49.33 \pm 11.4$ & $36.66 \pm 7.94$ & & \\
\hline
\end{tabular}

No: Number

SD: Standard Deviation

MAC: Mid-Arm Circumference

$\mathrm{t}=$ Student $\mathrm{t}$ test

$\mathrm{X}^{2}$ Chi square test

P Probability

* Statistically significant

American Research Journal of Pediatrics

Page 15 
Early Prediction of Premature Atherosclerosis in Children with End Stage Renal Disease(ESRD) on Regular Haemodialysis, A Single Centre Experience

Table2. Laboratory Data of Studied Patients and Controls

\begin{tabular}{|c|c|c|c|c|c|}
\hline & & Patients & Control & t. test & p. value \\
\hline \multirow{3}{*}{$\begin{array}{c}\text { Serum creatinine } \\
(\mathrm{mg} / \mathrm{dl})\end{array}$} & & $(\mathrm{No}=15)$ & $(\mathrm{No}=5)$ & & \\
\hline & Range & $4.5-9.4$ & $0.3-0.9$ & \multirow[t]{2}{*}{20.220} & \multirow[t]{2}{*}{0.001} \\
\hline & Mean \pm SD & $6.96 \pm 1.37$ & $0.63 \pm 0.15$ & & \\
\hline \multirow{2}{*}{$\begin{array}{c}\text { Blood Urea } \\
\text { (mg/dl) }\end{array}$} & Range & $95-164$ & $15-35$ & \multirow[t]{2}{*}{19.632} & \multirow[t]{2}{*}{0.001} \\
\hline & Mean \pm SD & $118.6 \pm 22.8$ & $28.86 \pm 6.64$ & & \\
\hline \multirow{2}{*}{$\begin{array}{c}\text { Serum Albumin } \\
(\mathrm{g} / \mathrm{dl})\end{array}$} & Range & $3.4-4.5$ & $4-6$ & \multirow[t]{2}{*}{3.317} & \multirow[t]{2}{*}{0.001} \\
\hline & Mean \pm SD & $3.94 \pm 0.27$ & $5.11 \pm 0.59$ & & \\
\hline \multirow[t]{2}{*}{$\mathrm{Hb}(\mathrm{g} / \mathrm{dl})$} & Range & $6-10.6$ & $11.5-13.5$ & \multirow[t]{2}{*}{9.052} & \multirow[t]{2}{*}{0.001} \\
\hline & Mean \pm SD & $8.11 \pm 1.99$ & $12.2 \pm 0.65$ & & \\
\hline \multirow[t]{2}{*}{ CRP (mg/l) } & Range & $6-48$ & $0.6-0.9$ & \multirow[t]{2}{*}{18.95} & \multirow[t]{2}{*}{0.001} \\
\hline & Mean \pm SD & $37.5 \pm 7.52$ & $0.7 \pm 0.08$ & & \\
\hline
\end{tabular}

No: Number

SD: Standard Deviation

Hb: Hemoglobin

CRP: $\mathrm{C}$ reactive protein

$\mathrm{t}=$ Student $\mathrm{t}$ test

P Probability

* Statistically significant

Table3. Lipid Profile and Common Carotid Artery Intima Media Thickness(CCA-IMT) of the Studied Patients and Controls

\begin{tabular}{|c|c|c|c|c|c|}
\hline & & Patients & Control & t. test & p. value \\
\hline \multirow{2}{*}{$\begin{array}{c}\text { HDL } \\
(\mathrm{mg} / \mathrm{dl})\end{array}$} & Range & $24-36$ & $41.2-49.1$ & \multirow[t]{2}{*}{21.358} & \multirow[t]{2}{*}{$<0.001$} \\
\hline & Mean \pm SD & $29.32 \pm 3.78$ & $45.25 \pm 2.79$ & & \\
\hline \multirow{2}{*}{$\begin{array}{c}\text { Triglycerides } \\
\text { (mg/dl) }\end{array}$} & Range & $130-176$ & $55-96.7$ & \multirow[t]{2}{*}{35.256} & \multirow[t]{2}{*}{$<0.001$} \\
\hline & Mean \pm SD & $156.93 \pm 14.49$ & $77.44 \pm 13.15$ & & \\
\hline \multirow{2}{*}{$\begin{array}{c}\text { Cholesterol } \\
\text { (mg/dl) }\end{array}$} & Range & $185-285$ & $150-193$ & \multirow[t]{2}{*}{5.64} & \multirow[t]{2}{*}{0.002} \\
\hline & Mean \pm SD & $222.1 \pm 32.3$ & $159.6 \pm 29.8$ & & \\
\hline \multirow{2}{*}{$\begin{array}{c}\text { LDL } \\
(\mathrm{mg} / \mathrm{dl})\end{array}$} & Range & $48.9-532$ & $81.3-103.5$ & \multirow[t]{2}{*}{6.97} & \multirow[t]{2}{*}{$<0.01$} \\
\hline & Mean \pm SD & $150.06 \pm 22.63$ & $90.39 \pm 8.89$ & & \\
\hline \multirow{2}{*}{$\begin{array}{l}\text { CCA IMT } \\
\text { (um) }\end{array}$} & Range & $350-850$ & $225-415$ & \multirow[t]{2}{*}{18.250} & \multirow[t]{2}{*}{$<0.001$} \\
\hline & Mean \pm SD & $579.6 \pm 162.01$ & $336 \pm 52.8$ & & \\
\hline
\end{tabular}

No: Number

SD: Standard Deviation

CCA-IMT: Common Carotid Artery Intima Media Thickness

HDL: High Density Lipoprotein

LDL: Law Density Lipoprotein

t Student $t$ test

P Probability

* Statistically significant

American Research Journal of Pediatrics 
Early Prediction of Premature Atherosclerosis in Children with End Stage Renal Disease(ESRD) on Regular Haemodialysis, A Single Centre Experience

Table4. Correlations between Different Studied Parameters in Patient Group

\begin{tabular}{|c|c|c|c|}
\hline \multirow{2}{*}{ CCA-IMT } & Dialysis duration & r value & P value \\
\cline { 2 - 4 } & Serum albumin & 0.291 & $0.047^{*}$ \\
\cline { 2 - 4 } & Triglyceride & -0.229 & $0.049^{*}$ \\
\cline { 2 - 4 } & HDL & 0.455 & $0.019^{*}$ \\
\hline \multirow{2}{*}{ HDL } & Serum albumin & -0.411 & $0.019^{*}$ \\
\cline { 2 - 4 } & Dialysis duration & 0.399 & $0.028^{*}$ \\
\hline \multirow{2}{*}{ Triglyceride } & Serum albumin & -0.339 & $0.021^{*}$ \\
\cline { 2 - 4 } & Dialysis duration & -0.400 & $0.031^{*}$ \\
\hline
\end{tabular}

CCA-IMT: Common Carotid Artery Intima Media Thickness

HDL: High Density Lipoprotein

r Correleation Coefficient

P Probability

* Statistically significant

Fig1. Correleation between CCA-IMT(um) and Serum Level of Dialysis Duration in Patients Group.

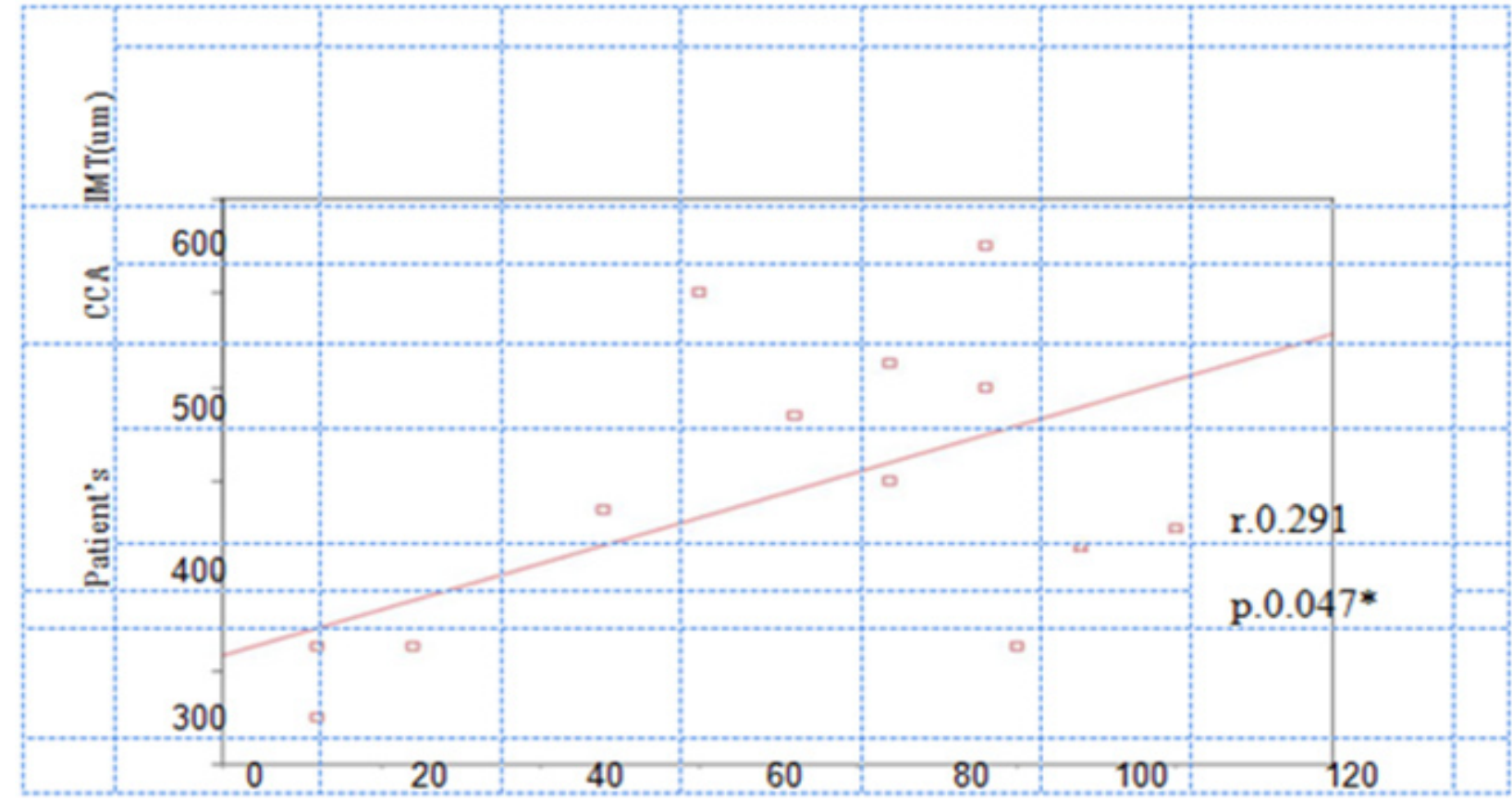

Duration of dialysis (months) 
Early Prediction of Premature Atherosclerosis in Children with End Stage Renal Disease(ESRD) on Regular Haemodialysis, A Single Centre Experience

Fig2. Correleation between CCA-IMT(um) and Serum Level of Triglycerides in Patients Group.

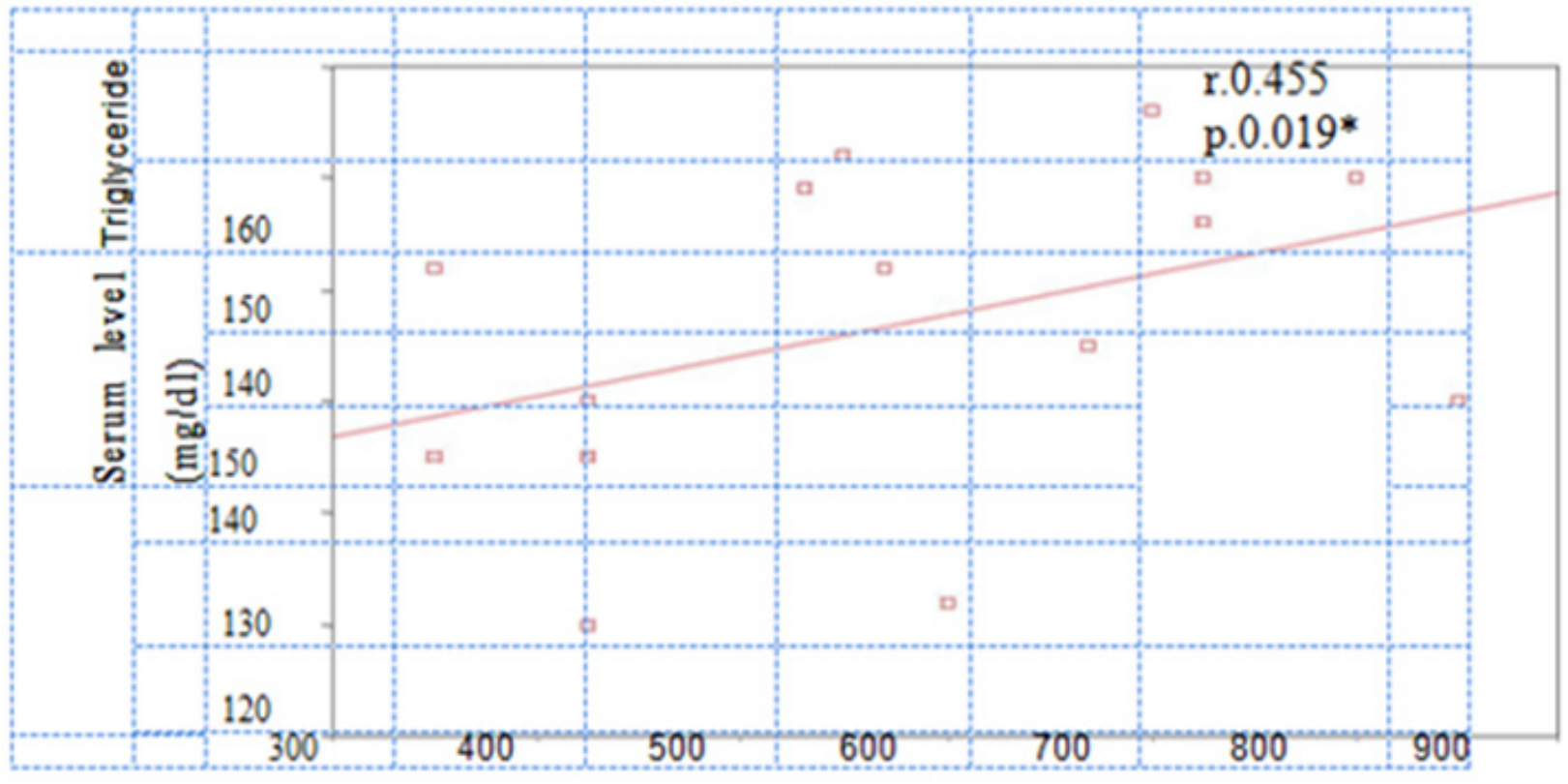

Patient's CCA IMT (um)

Fig3. Correleation between CCA-IMT(um) and serum levelof HDL in patients group.

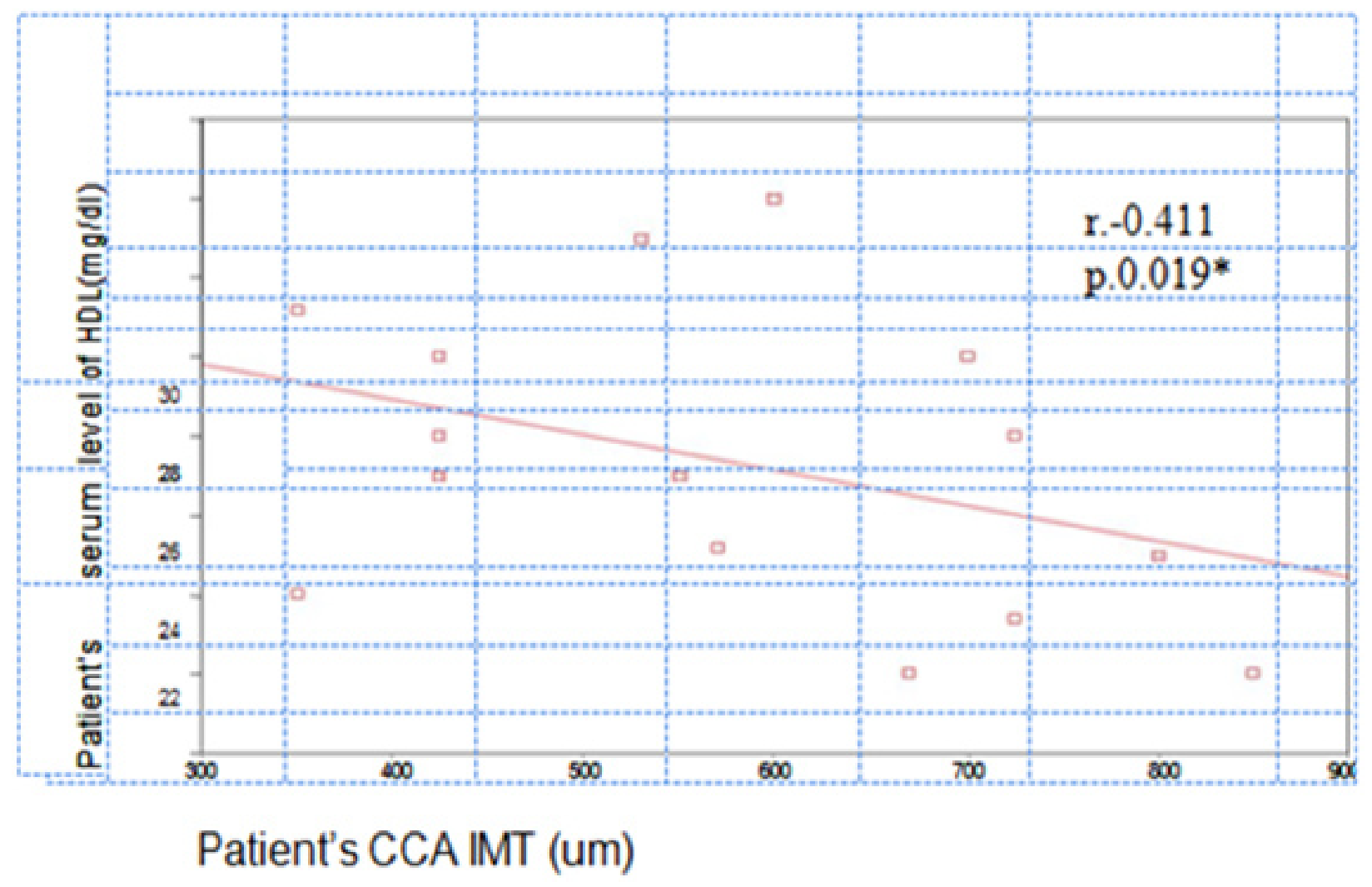


Early Prediction of Premature Atherosclerosis in Children with End Stage Renal Disease(ESRD) on Regular Haemodialysis, A Single Centre Experience

Fig4. B-mode Ultasonographic Image of the Left Common Carotid Artery of One of Controls Showing no Calcification and Normal CCA-IMT(0.3 $\mathrm{mm})$.

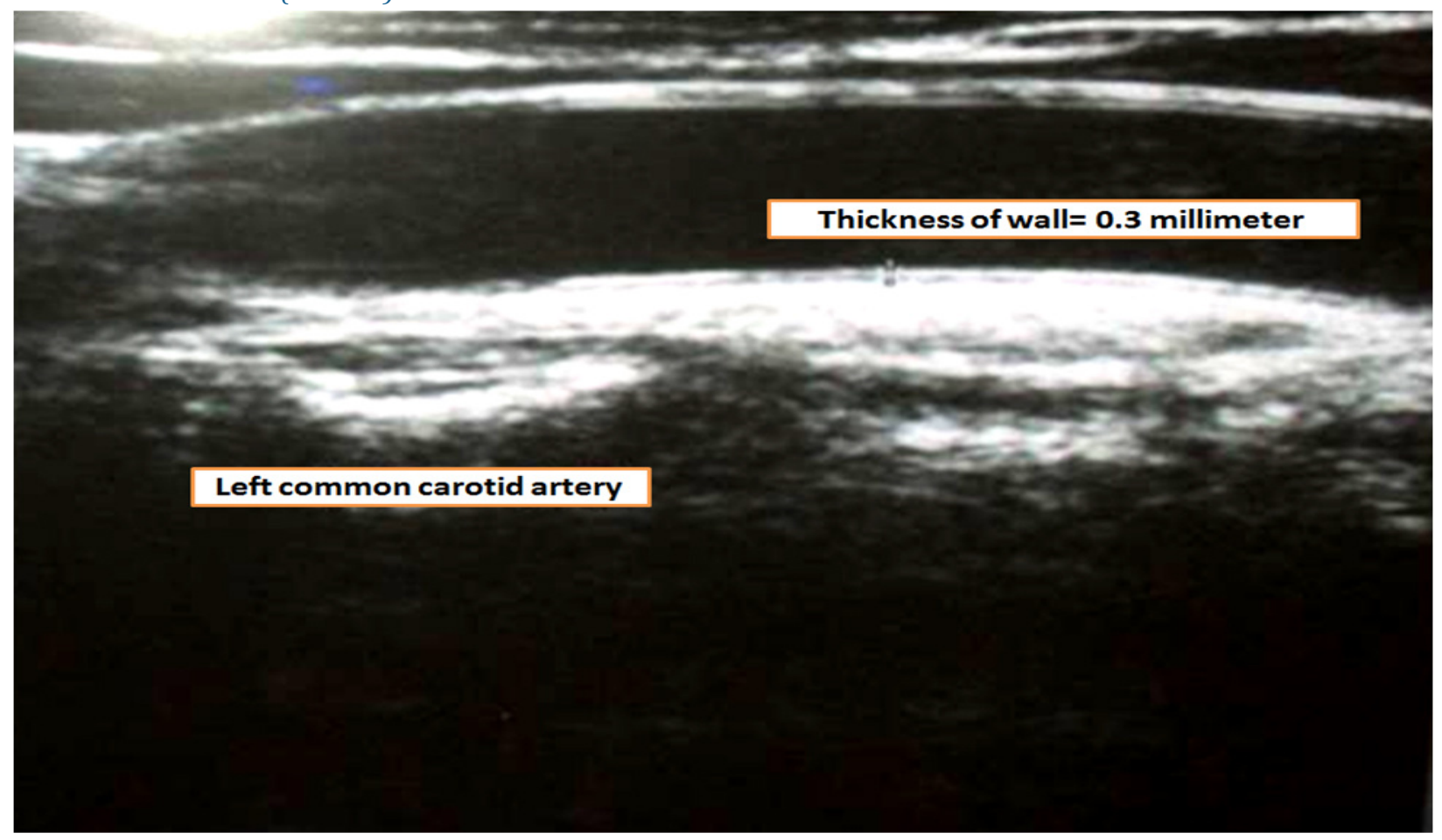

Fig5. B-mode Ultrasonographic Image of the Right Common Carotid Artery of One of Studied Patients Showing Two Calcified Plaques (white arrows).

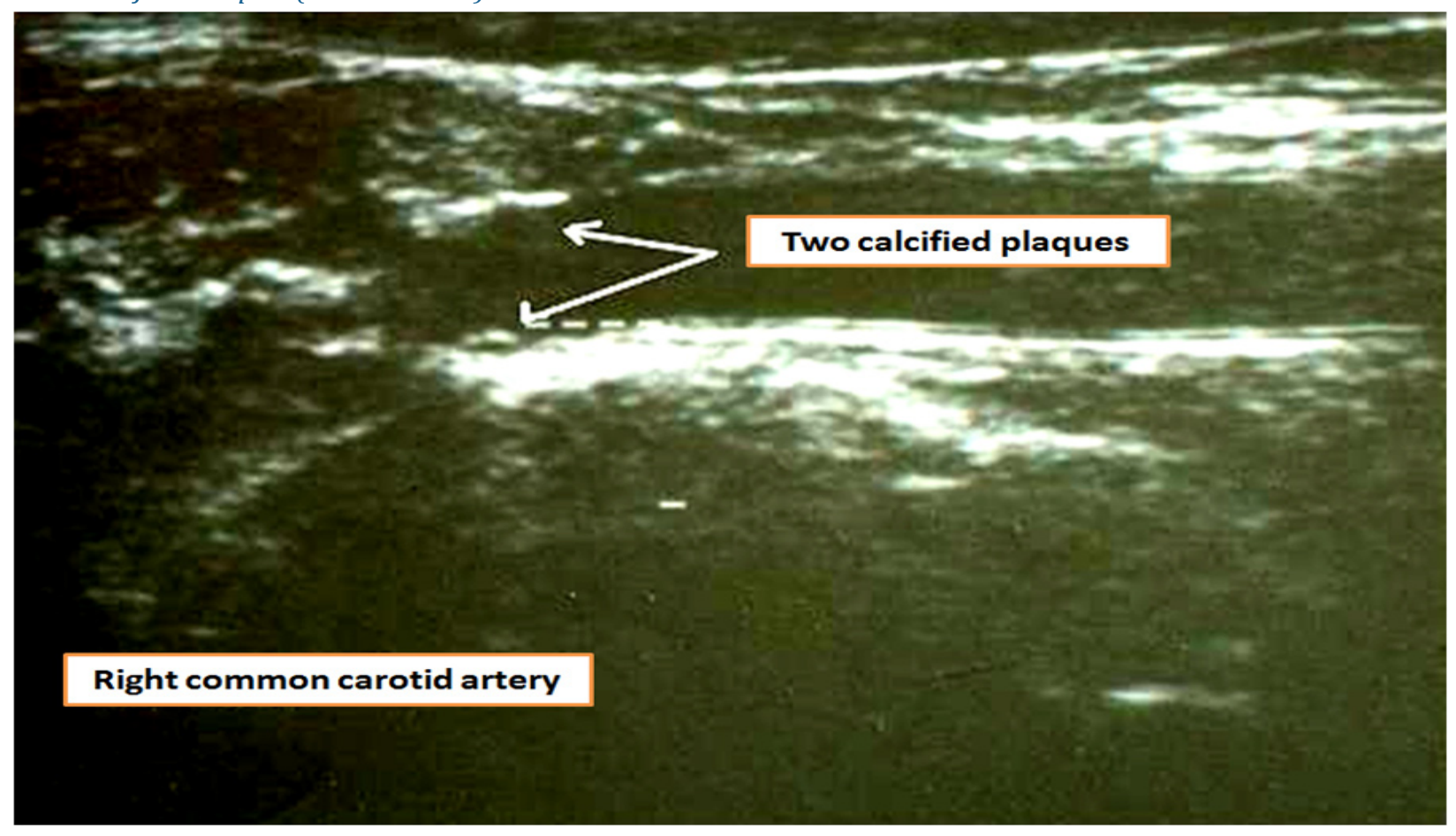


Early Prediction of Premature Atherosclerosis in Children with End Stage Renal Disease(ESRD) on Regular Haemodialysis, A Single Centre Experience

\section{DISCUSSION}

Although CKD patients are commonly burdened with multiple cardiovascular risk factors, Dyslipidemia is a known, frequent, highly prevalent and potentially modifiable risk factor for atherosclerosis in both adults and children with CKD. $(13,14,15)$. In the present study, children with ESRD on regular HD were investigated for dyslipidemia and its relation to dialysis duration, serum albumin and CCA-IMT as a predictor of atherosclerosis.

Our patients had a characteristic dyslipidemia in form of hypertriglyceridemia and reduced serum levels of HDL, whereas serum levels of LDL and total cholesterol levels remain in normal range as in controls. These findings are consistent with many previously done studies in both children (1) and adults (16) on regular HD. In contrary to our results, other studies reported that total serum cholesterol levels were elevated in children on regular HD (17), post-transplantation (18) and in children on chronic peritoneal dialysis $(\mathbf{1 9}, 20,21)$. The discrepancy in results may be explained by different epidemiological factors and variable nutritional status in patients compared to the patients in our study. Low serum cholesterol levels in the sitting of ESRD regularly on HD was reported by Kopple, 2005 and was associated with higher mortality which may be due to the high rates of malnutrition and inflammation among these patients (22).

Most studies that tried to elucidate the pathogenesis of lipid abnormalities in HD patients found reduced lipoprotein lipase, and markedly elevated concentrations of apolipoprotien C-III (23). However the patho physiologic mechanisms leading to dyslipidemia in CRF are still an active area of research. They may be due to insulin resistance, non nephrotic range proteinuria, malnutrition, intrinsic or genetic differences in individual metabolism (24 \& $25 \& 26)$.

In addition, decreased antioxidant activity and loss of carnitine which plays an important role in facilitating the transport of fatty acids across the inner mitochondrial membrane prior to beta oxidation, is common in HD patients. In the present study, malnutrition was evident in the patients as shown by the significant decrease in anthropometric measurements and hypo albuminemia when compared to the controls. Although serum albumin levels may be influenced by many factors, they are considered a marker for nutritional status. The significant negative correlation between serum albumin and serum TG levels, while significant positive correlation between serum albumin and HDL levels suggests that nutritional status is an important factor in the development of uremic dyslipidemia. (25),

The positive CRP in patients of the present study indicates that uremic children have a state of chronic inflammation resulting from various factors: elevated cytokine production, reduced renal clearance, un detected persistent infections, and dialysis related factors. CRP is an excellent marker of systemic inflammation that may impair endothelial function. Endothelia dysfunction may result in decreased endothelial cell delipidation of very low density lipoprotein (VLDL) predisposing to dyslipidemia in addition to the cardiovascular risk. However, a report in children did not observe a relationship between endothelial dysfunction and CRP levels and raised a debate whether CRP is a pathogenic mechanism or epiphenomenon (25).

Studies in adults on chronic HD place malnutrition-inflammation complex at the center of a debate about the role of traditional and non traditional risk factors for poor CV outcome (26). The studies have shown that in adults on chronic HD low blood pressure, low body mass index (BMI), low serum cholesterol and low serum homoctsteine are often correlated with unfavorable clinical outcome, malnutrition-inflammation complex causes a low BMI, hypocholesterolemia and low homocysteine levels. The introduction of high resolution ultrasnography (US) has provided a reliable, reproducible and non invasive method to detect and monitor the progression of subclinical atherosclerosis.It is well known that in the general population subclinical atherosclerosis begins in childhood and it is very likely that this process is accelerated in children with CKD (27). 
Early Prediction of Premature Atherosclerosis in Children with End Stage Renal Disease(ESRD) on Regular Haemodialysis, A Single Centre Experience

The present study was conducted on children with ESRD, previously published Egyptian researches studied CCA-IMT in children with chronic kidney disease (CKD) and concluded that CCA-IMT was statistically higher in children with ESRD under regular HD than children with chronic renal failure under conservative treatment and added both groups had a higher CCA-IMT than their control children (28). The present study found a significant increase in CCA-IMT in the patients compared to controls (mean value 579.6 \pm 162.01 um versus $336 \pm 52.8 \mathrm{um}$ ) $(\mathrm{P}<0.001)$. These values were near results of Abu Zeid A et al(795 \pm 251 um versus $383 \pm 50)$ (28). And ElGamasy MA et al $(612.3 \pm 153.78$ um versus $336 \pm 52)(29)$ This findings were higher than results reported in some studies both in children $(30 \& 31 \& 32)$ and adults $(33,34)$ on regular HD. We can explain this by many factors including increased levels of CCA-IMT with increased age $(\mathbf{2 8}, \mathbf{3 0}, \mathbf{3 1})$, different ages, races, ethinicity and associated hypertension and hyperlipidemia in different studies.

In contrary to our results, Groothoff et al., 2002 found that there is no difference in CCA- IMT in patients with ESRD on HD and controls. This difference may be explained by the shorter duration on dialysis, the difference in nutritional status and pattern of dyslipidemia compared to our patients (20)

The pattern of dyslipidemia in our patient is atherogenic as indicated by the positive correlation found between CCA-IMT and TG levels while the correlation was negative with HDL. There is strong epidemiological evidence that HDL exerts a protective effect against atherosclerosis independent of the effect of LDL (35).

Damjanovic and Dimkovic, evaluated CCA-IMT in 45 children on regular dialysis and found higher mean of CCA-IMT in HD patients compared to controls. He showed positive correlation between CCA-IMT with risk factors for atherosclerosis (Age, duration on dialysis and lipid profile). (27)

Dyslipidemia is associated with increased risk of vascular disease in adult with ESRD (36). A small autopsy series of children with ESRD or post-kidney transplantation showed pathologic changes in the intima of the coronary arteries and a cross sectional study evaluating coronary artery calcification by electron beam computed tomography also supported accelerated coronary artery disease. (37). Thus ESRD are considered major risk factors for CV disease among clinicians evaluating patients with dyslipidemia.

The correlation between CCA-IMT and pulse pressure in our study indicates that arteriosclerosis leads to arterial stiffness and increased peripheral resistance and these factors oppose left ventricle (LV) ejection and leads to increased LV workload and concentric LV hypertrophy.

Litwin et al., (2005), as a part of the ESCAPE trial, investigated vascular structure and function in children with CRF. The author demonstrated vascular abnormalities in all patient groups with the most marked changes in the dialysis patients with hyperphosphatemia, hyperparathyroidism and the treatment with Ca containing phosphate binders were the determinants of arterial abnormalities. Another important observation in this study was a significantly lower CCA-IMT in children post-transplants, suggesting that the vascular abnormalities partially regress. (32)

The correlation between dialysis duration and lipid abnormalities from one side and IMT from the other side indicates the role of uremic milieu in the pathogenesis of dyslipidemia predisposed to vascular changes. This may emphasis the important of renal transplantation in eliminating many uremia related risks and reducing the risk of cardiac death by approximately 80 percent (38).

One of limitations of our study was small sized sample that limited our conclusions.

\section{CONCLUSIONS}

From the present study we conclude that children with ESRD on regular haemodialysis are vulnerable to develop dyslipidemia, which is characterized by hypertriglyceridemia, hypercholesterolemia, increased serum LDL and reduced serum HDL levels. The malnutritional status and chronic inflammation are important factors 
Early Prediction of Premature Atherosclerosis in Children with End Stage Renal Disease(ESRD) on Regular Haemodialysis, A Single Centre Experience

in development of uremic dyslipidemia. The longer the duration of dialysis, the more frequent the occurrence of dyslipidemia, the more increase in CCA-IMT in patients. Dyslipidemia was associated with increased risk of atherosclerosis in ESRD patients, which is predicted by increase in CCA-IMT.

\section{RECOMMENDATIONS}

Regular follow-up of children with ESRD by cardiovascular examination by blood pressure monitoring, assessment of lipid profile and echocardiographic assessment for regular measurement of CCA-IMT as easy accurate and non invasive method to build strategies to control these risk factors. The availability of program for cadaveric renal transplantation may decrease time on dialysis and improve patient outcome. Correction of malnutrition and decrease factors lead to the occurrence of inflammation in patients with ESRD on regular haemodialysis may be helpful to improve dyslipidemia in children under HD.

\section{REFERENCES}

1. Cengiz NE, Baskin PI, Agras N, Sezgin and Saatci U.: Relationship between chronic inflammation and cardiovascular risk factors in children on maintenance haemodialysis.Transplant. Proc 2005; 37: 2915-17.

2. Parekh DJ, Jung C, Roberts R, Shappell S, Smith JA Jr. Primary neuroendocrine carcinoma of the urethra. Urology. December 2002; Volume 60, Issue 6, Page 1111 PMID:12475683

3. Fin RN, Whyte DA and Boydstun: Conservative management of chronic renal insufficiency. In: Pediatric nephrology, Avner ED, Harman WE, Niaudet P(edtors), 5th ed, Phladelphia 2004; 129-311

4. Asayama KA, Lto C, Nakahara A, Hasegawa and Kato K.: Lipid profiles and lipase activities in children and adolescents with chronic renal failure treated conservatively or with haemodialysis or transplantation. Pediatric Res 1984; 18: 783-788.

5. Querfeld U .Is atherosclerosis accelerated in young patients with ESRD? The contribution of pediatric Nephrology. Nephro Dial Transplant 2002; 17; 719-22.

6. Friedewald WT, Levy RI and Fredrickson DS. Estimation of the concentrations of low density lipoprotein cholesterol in plasma without use of preparative ultracentrifuge. Clin Chem 1972; Jun; 18(6): 499-502.

7. Warnick GR, Mayfield C, Benderson J, Chen JS and Albers JJ. HDL cholesterol quantitation by phosphotung state-Mg2+ and by dextran sulfate-Mn2+-polyethylene glycol precipitation, both with enzymic cholesterol assay compared with the lipid research method.Am J Clin Pathol 1982; Nov; 78(5): 718-23.

8. Warnick GR, Nguyen T, Bergelin RO, Wahl PW andAlbers JJ. Lipoprotein quantification: an electrophoretic method compared with the Lipid Research Clinics method. Clin Che8m 1982; Oct; 28(10): 2116-20.

9. Guerin M,Lassel TS, Le Goff W, Farnier M and Chapman MJ. Action of atorvastatin in combined hyperlipidemia : preferential reduction of cholesteryl ester transfer from HDL to VLDL1 particles. Arterioscler Thromb Vasc Biol 2000; Jan; 20(1): 189-97..

10. Jun,O.; Wunsch, R. And Turzer, M. Relationship to treatment method and atherosclerotic disease. J. Am. Soc. Nephrol; 10: 594-600.

11. Mohamed, C, Andrade J, C, Ignaszewski A, C and Mancini C .Validity of carotid intimal-medial thickness as a surrogate endpoint for atherosclerosis: Britsh Columbia medical journal( CMJ)2009; Vol. 51, No. 4, May page168-172

12. Khothari CR: Research methodology, methods and Techniques, New Age International, (2012) Khothari CR(ed). New Delhi ( $2^{\text {nd }}$ ed.). Pp 95-97 
Early Prediction of Premature Atherosclerosis in Children with End Stage Renal Disease(ESRD) on Regular Haemodialysis, A Single Centre Experience

13. Foley RN, Parfrey PS and Sarnak MJ.: Clinical epidemiology of cardiovascular disease in chronic renal disease. Am J Kidney Dis 1998; 32: 112-119.

14. Kidney Disease Outcomes Quality Initiative (K/DOQI) 2003. Clinical Practice guidelines: bone metabolism and disease in CKD, National Kidney Foundation. Am. J. Kid. Dis 2003; 12(suppl 4): S1-S201

15. Ginsberg. HN. New perspectives on atherogenesis: role of abnormal triglyceride-rich lipoprotein metabolism. Circulation. 2002 Oct 15; 106(16): 2137-42. Review.

16. Tsimihodimos V, Dounousi E and Siamopoulos KC. Dyslipidemia in chronic kidney disease: an approach to pathogenesis and treatment. Am J Nephrol 2008; 28(6): 958-73. doi: 10.1159/000144024. Epub 2008 Jul 9. Review.

17. Delucchi H. Dinamarca, H and Gainza, H. Carotid intima-media thickness as a cardiovascular risk marker in pediatric end-stage renal disease patients on dialysis and in renal transplantation. Transplantation Proceedings 2008; 40, 3244-3246.

18. Silverstein JH and Rosenbloom AL. Treatment of type 2 diabetes mellitus in children and adolescents. J Pediatr Endocrinol Metab 2000; 13 Suppl 6: 1403-9. Review.

19. Kasiske BL. Hyperlipidemia in patients with chronic renal disease. Am J Kidney Dis 1998 Nov; 32(5 Suppl 3): S142-56.

20. Groothoff JW, Gruppen MP, Offringa M, de Groot E, Stok W, Bos WJ,et al. Increased arterial stiffness in young adults with end-stage renal disease since childhood. J Am Soc Nephrol 2002 Dec;13(12): 2953-61.

21. Kimak E, Ksiazek A and Solski J. Disturbed lipoprotein composition in non-dialyzed, hemodialysis, continuous ambulatory peritoneal dialysis and post-transplant patients with chronic renal failure. Clin Chem Lab Med 2006; 44(1): 64-9.

22. Kopple JD, Kalantar-Zadeh K and Mehrotra R. Risks of chronic metabolic acidosis in patients with chronic kidney disease. Kidney Int Suppl. 2005 Jun;(95):S21-7. Review.

23. O'Neal D, Hew FL, Sikaris K, Ward G, Alford F and Best JD. Low density lipoprotein particle size in hypopituitary adults receiving conventional hormone replacement therapy.J Clin Endocrinol Metab. 1996 Jul;81(7):2448-54.

24. Packard DP, Milton JE, Shuler LA, Short RA, Tuttle KR. Implications of chronic kidney disease for dietary treatment in cardiovascular disease. J Ren Nutr 2006 Jul; 16(3): 259-68. Review.

25. Guarnieri G. Fighting protein energy wasting in chronic kidney disease: a challenge of complexity. J Ren. Nutr 2011

26. Nurmohamed SA. Reverse epidemiology :Paradoxical observations in hemodialysis patients. Netg J Med 2005.

27. Damjanovic T and Dimkovic N. Dialysis as risk factor for development of atherosclerosis. Med Pregl 2003; 56: 17-21.

28. Abu Zeid A, Twfeek D, Mohamed D, Khalifia N and Sobhy T. Risk factors of atherosclerosis and carotid intimal medial thickness as a new marker for itsdetection in children with chronic renal failure. Geget(Journal of the Egyptian Society for Pediatric Nephrology and Transplantation 2006; 6: 27-44.

29. El-Gamasy MA, Abdelmageed M, Eldeeb M and Nassar I: Indicators of Vascular Dysfunctions in Children with End Stage Renal Disease under Regular Haemodialysis as Paediatric Emergency. Journal of emergency and internal medicine. 2017; Vol.1 No.1: 6 
Early Prediction of Premature Atherosclerosis in Children with End Stage Renal Disease(ESRD) on Regular Haemodialysis, A Single Centre Experience

30. Schmidt-Trucksass A, Grathwohl D and Schmid A. Structural, functional and hemodynamic changes of the common carotid artery with age in male subjects. Aterioscler Thromb Vasc Biol 1999; 19: 1091-1097.

31. Drueke T, Witko-Sarsat V and Massy Z. Iron therapy, advanced oxidation protein products and carotid artery intima-medial thickness in ESRD, Circulation; 106: 2212.

32. Litwin M, Wühl E, Jourdan C, Trelewicz J, Niemirska A and Fahr K, et al. Altered morphologic properties of large arteries in children with chronic renal failure and after renal transplantation. J Am Soc Nephrol 2005 May; 16(5): 1494-500. Epub 2005 Mar 16.

33. Briese S, Wiesner S, Will JC, Opgen-Rhein B, Nissel R, Wernecke KD, et al.: Arterial and cardiac disease in young adults with childhood-onset end-stage renal disease: impact of calcium and vitamin $\mathrm{D}$ therapy. Nephrol Dial Transplant 21(7); 1906-14. Epub 2006 Mar 22.

34. Poyrazoğlu HM, Düşünsel R, Yikilmaz A, Narin N, Anarat R, Gündüz Z, et al. Carotid artery thickness in children and young adults with end stage renal disease.Pediatr Nephrol 2007 Jan; 22(1): 109-16. Epub 2006 Aug 30.

35. Mitsnefes MM, Kimball TR, Kartal J, Witt SA, Glascock BJ, Khoury PR, et al. Cardiac and vascular adaptation in pediatric patients with chronic kidney disease: role of calcium-phosphorus metabolism. J Am Soc Nephrol. 2005 Sep; 16(9): 2796-803. Epub 2005 Jul 27.

36. Shoji T, Nishizawa Y, Kawagishi T, Kawasaki K, Taniwaki H, Tabata T, et al. Intermediate-density lipoprotein as an independent risk factor for aortic atherosclerosis in hemodialysis patients.J Am Soc Nephrol 1998 Jul; 9(7): 1277-84.

37. Goodman W G, Goldin J and Kuizan BD: Coronary artery calcification in young adults with ESRD who are undergoing dialysis.N Engl J Med 2000; 342: 1472-83.

38. Kidney Disease Outcomes Quality Initiative (K/DOQI) 2005 : Clinical Practice guidelines for cardiovascular disease in dialysis patients. Am. J. Kid. Dis 2005; 45(4 suppl 3): S1-S153.

Citation: Dr. Mohamed A.El-Gamasy, "Early Prediction of Premature Atherosclerosis in Children with End Stage Renal Disease (ESRD) on Regular Haemodialysis, A Single Centre Experience". American Research Journal of Pediatrics; 1(1): 12-24.

Copyright (C) Dr. Mohamed A.El-Gamasy. This is an open access article distributed under the Creative Commons Attribution License, which permits unrestricted use, distribution, and reproduction in any medium, provided the original work is properly cited. 